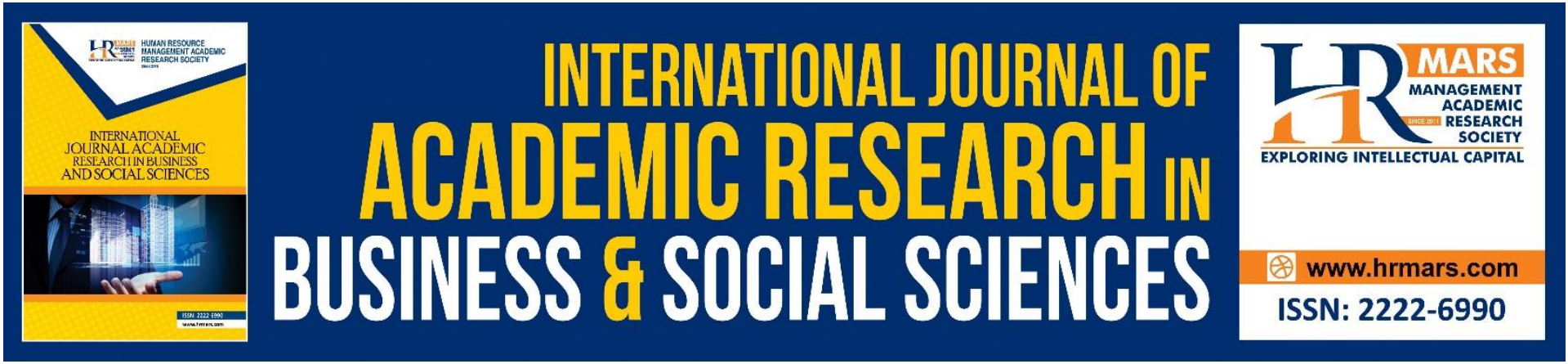

\title{
Approach to the Christianisation Movement among Orang Asli Muslim in State of Perak, Malaysia
}

\section{Zulkefli Aini \& Abdul Ghafar Don}

To Link this Article: http://dx.doi.org/10.6007/IJARBSS/v11-i6/10177

DOI:10.6007/IJARBSS/v11-i6/10177

Received: 11 April 2021, Revised: 14 May 2021, Accepted: 25 May 2021

Published Online: 12 June 2021

In-Text Citation: (Aini \& Don, 2021)

To Cite this Article: Aini, Z., \& Don, A. G. (2021). Approach to the Christianisation Movement among Orang Asli Muslim in State of Perak, Malaysia. International Journal of Academic Research in Business and Social Sciences, 11(6), 519-537.

\section{Copyright: @ 2021 The Author(s)}

Published by Human Resource Management Academic Research Society (www.hrmars.com)

This article is published under the Creative Commons Attribution (CC BY 4.0) license. Anyone may reproduce, distribute, translate and create derivative works of this article (for both commercial and non-commercial purposes), subject to full attribution to the original publication and authors. The full terms of this license may be seen at: http://creativecommons.org/licences/by/4.0/legalcode

Vol. 11, No. 6, 2021, Pg. 519 - 537

Full Terms \& Conditions of access and use can be found at http://hrmars.com/index.php/pages/detail/publication-ethics 


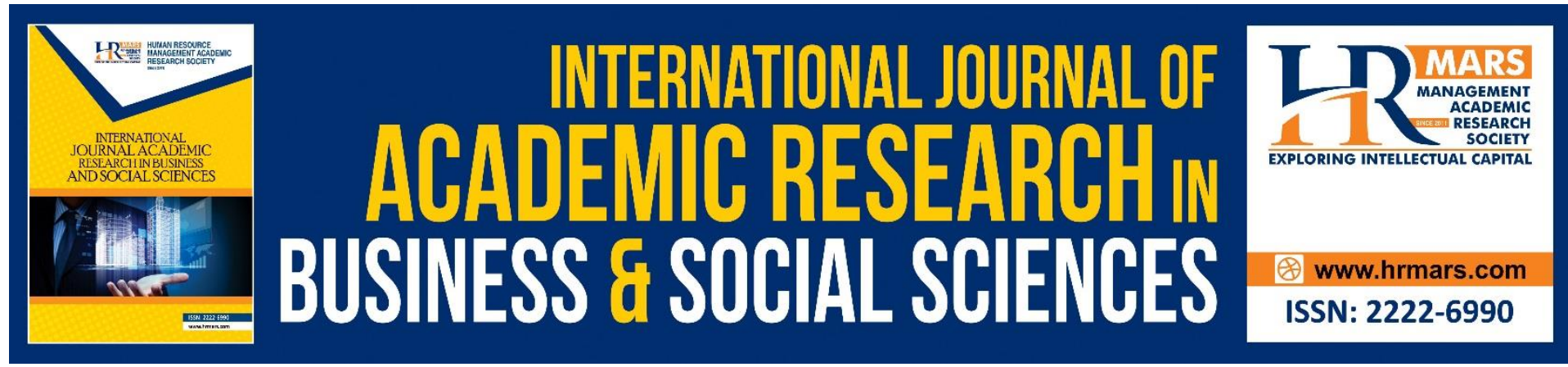

\title{
Approach to the Christianisation Movement among Orang Asli Muslim in State of Perak, Malaysia
}

\author{
Zulkefli Aini \& Abdul Ghafar Don \\ Centre for Da'wah and Leadership Studies, Faculty of Islamic Studies, National University of \\ Malaysia.
}

\begin{abstract}
Christian movement in Malaysia has been always a controversial debate among Muslims in Malaysia. Their efforts to Christianize Malaysian people including Orang Asli is regarded as a threat to Islam as a largest religion of Malaysia as well as an official religion of the state. This article attempts to analyze Christian missionary approach to deliver their Gospel messages among Orang Asli Muslim in Perak State of Malaysia, one of the 13 Malaysian states. This study focuses on the Orang Asli villages in Gopeng, Kampar and Tapah districts in Perak Darul Ridzuan. Data were collected through in-depth interviews using a semi-structured interview method conducted with six study participants as this is a qualitative research using case study design. The case study was conducted to examine in depth the phenomena related to the Christianization movement carried out by Christian activists through the experience of preachers who have been actively involved in preaching for more than 10 years in Orang Asli villages in Perak. The study found that Christian activities use a specific approach to attract the interest of the Muslim Orang Asli community to Christianity. Such an approach is a planned and structured strategy to win the heart of the Orang Asli. They carried out the effort so pragmatically and convincingly that the Orang Asli Muslims people could be influenced by the religion and eventually left Islam to embrace Christianity. The study also found that, the approach used to influence the Orang Asli community in Perak is the arts approach through entertainment, contextualization approach, humanitarian aid approach, psychological approach through the spread of love and affection message, and leadership cadres approach by appointing priests from the Orang Asli community.
\end{abstract}

Keywords: Approach, Christianisation Movement, Orang Asli, Muslim, Indigenous.

\section{Introduction}

Orang Asli are categorized as bumiputera in the main ethnic groups along with the Malays and natives of Sabah and Sarawak. Naming and identification as an Indigenous person are in accordance with the provisions of the law in 1954. This is because of the interpretation of the Orang Asli from a legal point of Malaysia, especially in the Constitution under Article 160 (2) of the Orang Asli of Peninsular Malaya. According to Act 134 (the Aboriginal Peoples Act, 1954; Amendment, 1974) under Article 3 (1) has been given a special interpretation of who can be accepted as the Orang Asli, namely: 
(a) any person whose male parent is or was, a member of an aboriginal ethnic group, who speaks an aboriginal language and habitually follows an aboriginal way of life and aboriginal customs and beliefs, and includes a descendant through males of such persons;

(b) any person of any race adopted when an infant by aborigines who has been brought up as an aborigine, habitually speaks an aboriginal language, habitually follows an aboriginal way of life and aboriginal customs and beliefs and is a member of an aboriginal community; or

(c) the child of any union between an aboriginal female and a male of another race, provided that the child habitually speaks an aboriginal language, habitually follows an aboriginal way of life and aboriginal customs and beliefs and remains a member of an aboriginal community.

According to the Department of Statistics Malaysia, Orang Asli are a minority in the bumiputera ethnic group with a population of the population in 2018 is 178,197 people or 0.5 percent of the total population of Malaysia. In terms of official administration, according to information from the Department of Orang Asli Development (JAKOA), the Malaysian government agency entrusted to oversee the affairs of the Orang Asli, there are three major Aboriginal groups, the Negrito, Senoi and Proto-Malay. Every race is divided into tribes or sub-group specific, ie there are six tribes each ethnic group (although according to Endicott (2016) ethnic Malay Proto there is one extra tribe of Temoq), as shown in Table 1 (Carey, 1976). According to Edo (2010), the Orang Asli community consists of three ethnic groups formed from 18 tribes. Each tribe is an ethnic entity that is unique and rich in their respective cultures. They exist as a society that adheres to the ancestral customs. The division of the Orang Asli by tribe is done according to the pattern of their settlement (Carey, 1976), the physical appearance, language and customs practiced by each group and tribe (Sam, 2015).

TABLE 1 Division of Indigenous Peoples by Ethnicity and Race

\begin{tabular}{rrr}
\hline Num. & Ethnicity & Tribes \\
\hline 1 & Negrito & Kensiu, Kintak, Lanoh, Jahai, Mandriq, Bateq \\
2 & Senoi & Che Wong, MahMeri, Jahut, Semoq Beri, Semai, \\
Temiar. & Semelai, Temuan, Orang Kuala, Orang Kanaq, \\
3 & Proto Malay & Orang Seletar, Jakun/Orang Ulu \\
\hline & Source: www.jakoa.gov.my
\end{tabular}

The distribution of Orang Asli community settlements in Peninsular Malaysia according to their respective tribes is as shown in TABLE 2. 
TABLE 2 Placement of Indigenous Peoples by State in Peninsular Malaysia

\begin{tabular}{llll}
\hline Num & Ethnicity & Tribes & State Placement \\
\hline 1 & Negrito & Kintaq & Perak \\
& & Kensiu & Kedah \\
& & Jahai & Perak, Kelantan \\
& Mendriq & Kelantan \\
& & Batek & Kelantan, Pahang \\
& & Lanoh & Perak \\
2. Senoi & Che Wong & Pahang \\
& Temiar & Perak, Kelantan \\
& Semai & Perak, Pahang, Selangor \\
& & Jah Hut & Pahang \\
& Semoq Beri & Terengganu, Pahang \\
& Mah Meri & Selangor \\
3. & Proto Malay & Semelai & Pahang, Negeri Sembilan \\
& Jakun & Pahang, Johor \\
& Temuan & Selangor, Negeri \\
& & Melaka \\
& & Orang & Johor \\
& Seletar & \\
& Orang Kanak & Johor \\
& Orang Kuala & Johor \\
\hline
\end{tabular}

Source: www.jakoa.gov.my

\section{Indigenous Beliefs and Islamization}

Studies show that the settlement of the Orang Asli population influences their sociocultural aspects in terms of daily economic activities, social systems, beliefs and ritual practices, systems of norms, customs and taboos, and language (Anon, 2002; Komar \& Amir Zal, 2014; Abdullah, 2014; Abdullah, 2015). In addition, it also affects the patterns and patterns of behavior, thoughts, values and activities of the society. Furthermore, according to Leary (1995), the Orang Asli, known as heterogeneous ethnic groups (Leary, 1995), are rich in customs and culture because of their environment which is still closely related to nature even though it has entered the modern world. Therefore, in the context of the beliefs and ritual practices of the Orang Asli community, they generally believe that human life is dominated by a power consisting of supernatural beings. Such power is believed to be the creator of nature and the cosmological system that exists in this universe, the guardian of human welfare, the controller of human behavior when in contact with nature. Due to that, they have certain taboos and customs associated with that power. Apart from that, they also believe in supernatural powers such as the spirits of dead ancestors and living humans who have a relationship with the powers of the supernatural. However, the beliefs, ritual practices, customs and taboos adhered to do not prevent them from interacting with the outside world. In fact, some of them are open to efforts to integrate their communities into mainstream society (Redzuan and Abdul Rahman, 2008). Their communication with the outside community has led them to receive various messages in the form of religion until they follow the religion introduced to them. Among the practitioners and adherents of animistic beliefs and ancestral customs, there are those who embrace Islam, Christianity, Buddhism, Bahai and Hinduism. 
Data from JAKOA in 2011 showed that the religious patterns of the Orang Asli community who embraced Animism were 58,043 people (33\%), Muslims 35,975 people (20\%), Christians as many as 17,351 people (9.8\%), other religions namely Buddhism as many as 1,024 people $(0.6 \%)$, Bahai as many as 5,071 people (2.8\%), Hindus as many as 261 people (0.1\%) and Religious Tribes as many as 14,975 people (8.4\%). While the Orang Asli who do not have a religion are 42,757 people $(24 \%)$ and others are a total of 2,740 people $(1.5 \%)$ (JAKOA, 2014).

In the context of Indigenous Islamization, it has gone various efforts and through certain phases and stages (Aini \& Don, 2020). However, their Islamization rate as shown in JAKOA (2014) data, is about $20 \%$ of the whole Orang Asli population which is is still considered low. Furthermore, according to Abdullah $(2019,2015)$ and Don $(2014)$, the quality of their practice of Islam is also at a low level. In fact, from the point of view of their religious appreciation in matters related to Islamic belief and practice is also at a low level (Aini et al., 2019). Among the effects is that they are easily influenced and swayed by the call and persuasion of a missionary-like religion such as Christianity. This causes some of them to apostatize and embrace Christianity (Hussin, 2009).

According to Zain and Alwi (2017), the standard of living and the level of closedmindedness of some Orang Asli communities cause them not to miss being the main target of the Christian missionary mission to influence their beliefs and faith. In the study of Nor (1994) the Christianization movement using certain strategies and approaches based on the strength of financial funds can attract the Orang Asli to embrace Christianity even though they have embraced Islam. Furthermore, according to Fui (1997), some Orang Asli have been appointed as assistant priests by being given attractive salaries and remuneration and given financial and material assistance. Such influence makes them more vulnerable because for them the approach taken by Christian activists is not against the lusts and desires of their lives. This is compounded by their low economic position resulting in such aid touching their feelings and causing them to eventually choose to leave Islam and then embrace Christianity (Hussin, 2009).

\section{Historical Development of Christianisation Among Orang Asli}

The efforts of Christianizing indigenous people in Malaya can be attributed to the efforts of a Catholic priest named $\mathrm{M}$. Borie from a missionary body in France known as the Society of the Foreign Mission of Paris in 1847 (Basri, 2014). He is said to have made efforts to spread Christian teachings among the Mantra (Temuan tribe) found around the city of Melaka. From here, this group split up and migrated to the area of Labu, Lukut Negeri Sembilan. In fact, according to Mohamed and Isa (2009), the Christianization movement intensified when they began to approach the Orang Asli community of the Semai tribe around 1932 and they have extended financial assistance to this tribe which is specifically allocated from two International Christian organizations namely, The Elca Division For Global Mission and The Southeastern Synod.

Meanwhile, Sahad and Sa'ari (2005) view the early history of the entry of Christianity among the Orang Asli in Peninsular Malaysia as said to have started in Perak before the Second World War. Meanwhile, Sahad and Sa'ari (2005) view the early history of the entry of Christianity among the Orang Asli in Peninsular Malaysia is said to have started in Perak before the Second World War. However, their efforts were less successful. They have therefore changed their approach by appointing from among the Indigenous people themselves to carry out Christian missionary efforts with attractive remuneration. According to Nicoholas et al. 
(1989), this effort is seen as a success because the Orang Asli are more easily persuaded by their own tribes as well as their efforts, although not seen to achieve full success, but still considered better and more successful than the efforts made by teachers -Islamic teachers. Then, after a hundred years later other denominations such as Protestants, especially from the Methodist Home Missionary Society also began their activities (Basri, 2014).

According to Hussin (2009), they took the opportunity to infiltrate the Orang Asli of the Semai tribe in the districts of Gopeng, Kampar, Tapah and Teluk Intan in Perak. Then by 1930 the effort was continued by a married couple named Reverend Dr. Paul and Mrs. Nathalie Means with the help of a Batak missionary from Indonesia in an effort to develop and advance Christianity. Similarly, like the chief priest named Napitoepoloe, he married Orang Asli women and succeeded in Christianizing more than six Orang Asli at that time (Sahad \& Sa'ari, 2005). Carey's (1976) study found that Napitoepoloe had successfully produced three books on Christianity in the Semai language and these books are still said to be widely distributed among the Aboriginal people.

Meanwhile, in the study of Musa (1996) found that at that time the town of Kampar was used as a center for church educational activities to train prospective priests. According to records between 1961-1970 a total of 275 Orang Asli, youth and children have received formal education in Kampar through church education. By 1966 there were about 950 Indigenous people successfully Christianized. By 1970 the number had increased to 2940 people occupying several areas of 15 villages around Gopeng and Tapah. Later in 1991, the Aboriginal church was awarded as an official body with autonomous status from the central church by the name of Sengoi Mission Conference. At that time there are 12 pastors among Semai children who work full time to supervise and manage a total of 4500 Methodist denomination Christians throughout the State of Perak (Basri, 2014).

According to Nor (1994); Hussin (2009), until 1990 the Methodist church in Kampar confirmed that there were a total of 5,026 Indigenous Christians who were Christianized and embraced the Methodist denomination. At that time there were 2,000 Catholics and about 1000 people had chosen Christianity from other denominations. This shows that the number of Christians among the Orang Asli throughout peninsular Malaysia in 1990 was more than 8000 people. Methodist Christian activists began their activities in the Orang Asli community after 1930 and their chances of settling in the Orang Asli community began when Dr. Paul Means and his wife Nathalie Means were invited to visit the Orang Asli community in Kuantan Pahang. During this visit, he had the opportunity to visit the Orang Asli around Jalan Pahang from Tapah to Cameron Highlands. As a result of the survey, he thinks that Christian teachings can be spread through the leaders of Orang Asli community groups (Basri, 2014).

\section{Objective of the Study}

Based on an above discussion related to development of Christianisation efforts to Orang Asli community, in fact this article attempts to analyse Christian missionary approach to deliver their Gospel messages among Orang Asli Muslim in Perak State of Malaysia, one of the 13 Malaysian states.

\section{The Approach of Christian Movement to Orang Asli Muslim}

This study focuses on the Orang Asli villages in Gopeng, Kampar and Tapah districts in Perak Darul Ridzuan, Malaysia. Data were collected through in-depth interviews using a semistructured interview method conducted with six study participants as this is a qualitative research using case study design. The case study was conducted to examine in depth the 
phenomena related to the Christianization movement carried out by Christian activists through the experience of preachers who have been actively involved in preaching for more than 10 years in Orang Asli villages in Perak, namely the Assistant Director of Da'wah Division and Islamic Affairs Assistant of Perak Islamic Affairs Department, Malaysia (JAIPk), Penggerak Masyarakat Orang Asli (PMOA), or Muslim social worker to Orang Asli, appointment of the Department of Islamic Development Malaysia (JAKIM) and Muballigh Is/am ${ }^{1}$ or Muslim Preacher appointment Islamic Religious Council and Perak Malay Custom, Malaysia (MAIPk), as well as the Orang Asli villagers who convert from Islam to embrace Christianity and Christian pastors who agreed to be study participants. However, the priest withdrew for some reason. The selected study area is shown in table 3 below.

Table 3: Study Participants

\begin{tabular}{|c|c|c|}
\hline $\begin{array}{l}\text { Study } \\
\text { Particip } \\
\text { Code }\end{array}$ & Gender & Position \\
\hline PK1 & Male & Muballigh Islam of Batu Gajah District \\
\hline PK 2 & Male & Assistant Director of Dakwah Division, JAIPk \\
\hline PK 3 & Male & Assistant for Islamic Affairs, JAIPk \\
\hline PK 4 & Female & Kampar District PMOA \\
\hline PK 5 & Male & Tapah District PMOA \\
\hline PK 6 & Female & Orang Asli of the Semai tribe who left of Islam. \\
\hline
\end{tabular}

Source: Field Research 2019

The construction of the interview instrument is based on the objectives of the study determined by taking into account the information obtained from the literature review and categorized according to specific themes that are appropriate to the objectives of the study. The interview items were evaluated through a verification and reliability process by three experts consisting of two academicians from the Center for Da'wah Studies and Leadership of the Faculty of Islamic Studies, Universiti Kebangsaan Malaysia (UKM) who have expertise in the field of Islamic da'wah to Orang Asli community, and Academy for Civilisational Studies of Dar al-Hikmah College, Malaysia which has expertise in the field of Christianization movement in Malaysia; and an assistant director of the JAIPk da'wah division who has experience and skills in the field of $d a^{\prime}$ wah to Muslims and non-Muslims. The reliability process is done through Cohen's Kappa method. Analysis of interview data using thematic analysis methods based on specific codes that form the pattern of study findings. The data obtained through interviews with study participants were forwarded back to them for validation based on the analysis unit approval evaluation approach through Cohen's Kappa method.

The study found that Christian activities use a specific approach to attract the interest of the Muslim Orang Asli community to Christianity. Such an approach is a planned and structured strategy to win the hearts of the Orang Asli. They carried out the effort so pragmatically and convincingly that the Orang Asli Muslims people could be influenced by the religion and eventually left Islam to embrace Christianity. The study also found that, the

\footnotetext{
${ }^{1}$ Muballigh Islam is a position created in the state of Perak through the Islamic Religious Council and Perak Malay Custom or Majlis Agama Islam dan Adat Melayu Perak (MAIPk) to complete the missionary efforts for the Orang Asli and muslim converts. In terms of work organization, the Muballigh Islam are placed under the Da'wah Division of the Perak Islamic Religious Department. (www.maiamp.gov.my)
} 
approach used to influence the Orang Asli community in Perak is the arts approach through entertainment, contextualization approach, humanitarian aid approach, psychological approach through the spread of love and affection message, and leadership cadres approach by appointing priests from the Orang Asli community.

\section{Art Approach through Entertainment Medium}

The results of the study found that Christianity came to the Orang Asli community in Perak in a leisurely through an artistic approach using entertainment medium. According to PK4, Christian preachers are present among the Orang Asli community with these relaxing activities to be seen in the eyes of the Orang Asli that their presence is more friendly and more effective than the presence of PMOA and Islamic Missionaries. Since the behavior of the Orang Asli community is a group of people who are free and do not like to be controlled (Mokhtar and Aini, 2014) then according to PK1, this leisure method is more interesting for them to approach. Therefore, the Orang Asli community is more easily influenced by Christianity because the nature of the teachings is considered interesting because studies have found that Christian teachings come with an element of entertainment. In their view, Islam is seen as so rigid in determining entertainment activities that there can be no free association, alcohol drinking activities and so on.

According to PK1, Christian preachers observed the movement and cared about the activities carried out by PMOA and Islamic Missionaries while preaching. They made a perception of the interaction that took place between the preachers and the Orang Asli community by claiming that there were weaknesses in the communication process so that it was said to be boring on the part of the Orang Asli and did not express intimacy between them. This situation is different from the Christian movers who entered the Orang Asli villages. They use an entertainment approach that is seen to facilitate the Orang Asli to accept the arrival of the movers. The entertainment that is played is the rhythms of songs that are loved by teenagers and all walks of life of the Orang Asli community. The entertainment is accompanied by a simple dance. Such an approach is seen to be closer, more relaxed and friendly to them than the $d a^{\prime} w a h$ approach used by PMOA and Missionaries. This situation is exactly the same as Dana (2004) who used the music approach in the Christianization movement in Bukit Toraja Sulawesi. Although the Bukit Toraja community has traditional music used in certain ritual ceremonies and has become a hereditary heritage, Christian activists use western music to attract potential community members to become Christians and involve them in activities organized by the church.

According to PK4, the Christian mobilization effort to bring tourists from Korea has certain motives such as introducing the latest culture, entertainment and trends that can attract young people. This situation causes some Orang Asli teenagers to be influenced in such a way, especially K-pop (Korean pop) culture. Most of the most popular K-pop groups such as Miss A, Shinee, Nu'Est, Shinhwa, Wonder Girls and Super Junior are a group of Christians (Anon, 2019a) and some of them are Christian activists (Omar, 2012). Among the K-pop artists who sing Christian songs are Choi Siwon (a member of the group Super Junior) with the song "Who Am I", Kevin Woo (a member of the group U-Kiss) with the song "Above All" and Ailee with the song "Farther's Heart" (Anon, 2019b). In fact, according to Jalaudin and Ahmad (2011), Yahya and Annuar (2018) the obsession of teenagers towards K-pop artists has now become an extraordinary phenomenon. This is compounded by the success of K-pop music in the bottom 100 in the United States proving that their music is increasingly accepted and valued by the International community. Accordingly, in the view of Lee et al. (2020), it shows 
that the Korean wave (or known as Hallyu) through K-pop which is also an injection of popular culture was successfully exported and accepted by a number of residents of other Asian countries such as Malaysia and Indonesia. According to Choi (2019), the church needs to make changes by looking at the phenomenon of the entertainment world that afflicts teenagers, in particular, to attract them to follow Christian teachings. Taking the BTS group from Korea, Choi stated "The Western church should take note of the BTS phenomenon. There are a few lessons it can teach us about our changing world." He is of the view that the next generation that inherits the church institution and its leadership is a generation that is diverse and looks more diverse and ready to be influenced by leaders who are also diverse.

According to PK4, PMOA and Muslim preachers are now doing their best to follow the rhythm of the Orang Asli by bringing along artists while holding programs in Orang Asli villages. This effort is to ensure that Orang Asli participate in the program organized. However, the study found that the spirit of Christian music itself is more attractive to the Orang Asli to go to church than they attend to religious ceremonies conducted by PMOA and Muslim preachers. In fact, the attitude of the Orang Asli who are Muslims themselves who are excessively entertaining while singing and dancing compared to non-Muslims causes them to lose a good example in society. Finally, they conclude simply that there is no difference between Islam and Christianity in that regard.

\section{Contextualization Approach}

This study found that Christian activists used a contextualization approach that was considered non-aggressive and harmless to the Orang Asli community. However, according to PK3, such an approach is an obstacle and a challenge to preachers who strive to convey the teachings of Islam to them. Apart from that, PK4 is of the view that the Christianization movement carried out on the outside looks leisure and easily accepted and understood by the Orang Asli community. This is because they educated the Orang Asli community after embracing Christianity simply by holding that Jesus did not like enmity, and needed to be kind to everyone. Such a contextualization approach, according to Tanudjaja (2000) and Mashoko (2005) through the process of integrating Christian teachings through the bible with the culture of the local community. Every process of spreading, evangelizing and helping on the basis of Gospel teachings in the bible needs to be done in the context of the local community in terms of socio-cultural and economic.

In addition, according to PK5, Christian preachers will never force or threaten the Orang Asli to leave Islam, in fact they can convert to Christianity without showing any sign that they have apostatized. Those who are in such a situation are known as insider movement, that is, who are trusting in Christ as their Lord and Savior but choose to remain culturally and religiously identified as a Hindu or a Muslim. Therefore, Tennet (2019; 2005) undoubtedly concludes that "they are referred to as "insider" believers because they are following Christ within the religious and cultural structures of non-Christian religions. Not only that, they are also known as Churchless Christianity, which in Hoefer's (2001) view is considered Christian but is seen to remain in their original religious group, not showing any sign that they are Christians such as visiting the church and participating in activities and programs organized by the church Christian teaching is not taught in the church. They make the house a meeting place for activists and Christians. According to Hidajat (2018), the use of houses for Christian endeavors is beneficial for the social acceptance of the community outside of Christianity. They are more comfortable meeting as a Christian social group and escape public attention than in the church. This method is seen as a vigorous process of contextualization because it 
facilitates the process of spreading Christianity to others. They are also better known as faithful followers of Jesus and unbaptized Christian followers (Tennent, 2019).

According to Bridges (1997), they can continue to be in the mosque to worship exactly like a Muslim, but in terms of the fact that they are Muslim followers of Jesus who are always in the mosque, and do not stay away from the mosque. They are considered to be in Jesus Mosques in the sense of obeying Jesus' command even while in the mosque. In the writings of Hoefer (2015) revealed that one of the strategies of Christian activists like him to Christianize followers of other religions, especially Muslims and Hindus is to use a sociological approach in the context of associating religion with the values of a society. A Muslim does not have to go out of the values and attachments of the Muslim community to become a Christian. He can remain a member of the community in the Muslim community which has religious values such as worshiping in the mosque but in terms of the fact that they are a Christian. Thus, Heofer (2015) honestly says that:

"my goal is not to make them into a Christian (i.e., a member of a different sociological community). I tell them that I pray they would become a follower of Christ as a Muslim or a Hindu (sociologically). I have found that they easily understand this distinction, and they begin to drop their guard because they already have a very high regard for Christ from within their own religious tradition. Their primary hesitation is not because of a change of faith but a change of community. We of the church offer ourselves as "along siders" for these inside followers of Christ".

This insider movement and churchless Christianity approach is seen to be related to the "C-5" strategy in the Christianization movement (Tennet, 2019; 2005). According to Martin (2012), the "C-5" approach is a contextual approach or contextualization in the Christianization movement based on certain scales. Such a scale known as The C-Scale, or Contextualization Spectrum, is a tool used to measure the level of contextualization among Muslims in a particular context (Travis, 1998). Meanwhile, Williams (2011) in his study found that The C-Scale which has 6 scales (C1-C6), is "compares and contrasts types of 'Christcentered communities' (groups of believers in Christ) found in the Muslim world. In a real sense, then, the Spectrum delineates veritable "denominations" of Muslim background believers (MBB), separated along ecclesial and doctrinal lines. Hence through the $\mathrm{Cl}-\mathrm{C} 6$ Spectrum we see not only divisions between groups of MBBs, but also between those who analyze MBBs using the Spectrum". It actually meets the target focused by its founder Travis (1998) which is the standard reference in discussing the contextualization approach in the Islamic context.

The "C- 5 " scale is a scale of 5 which also refers to Christians who are in the Muslim community and maintain their Islamic identities without revealing Christian symbols. Other Muslims consider themselves to be Muslims (Martin 2012). They do not have to abandon their Islamic identity such as the name of Islam and the system of social relations required in Islam to become a Christian. In situations like this they, according to Basri $(2014,1994)$ are known as anonymous believers. "C-5" is also known as "high spectrum" in the contextualization approach (Tennent, 2006) among others also targets "MBBs who choose to stay within their community as" Muslims who follow Isa al-Masih "(Jesus the Messiah), with all the ramifications of that scenario "(Williams, 2011)

Thus, in the context of this study, there are Orang Asli who are categorized as apostates but pretend to obey the advice of PMOA and Islamic Missionaries such as wearing a headscarf and going to the mosque to perform prayers despite the fact that they have 
converted to Christianity. This is happening, according to PK3, because there are Orang Asli people who are like weeds and easily influenced by Christianity so that PMOA and Islamic Missionaries can not expect that they have apostatized. According to PK1, this non-aggressive Christian movement will result in the symptoms of apostasy among the Orang Asli community.

According to PK4, the contextualization approach used by Christian activists actively either secretly or silently. Their efforts are seen as not aggressive but still widespread. Neither the public nor the PMOA and the Muslim Missionaries who are less sensitive to the issue of Christianization cannot detect this tactic. Neither the public nor the PMOA and the Muslim Missionaries who are less sensitive to the issue of Christianization cannot detect this tactic. This silent approach, according to Basri (2014) is likened to a process of salt and leaven. It refers to the process of Christianization that is responsive and rooted in Christian teaching among new converts as well as growing quietly but effectively. For example, salt that penetrates into food ingredients such as meat for cooking or a grain of yeast acts to ferment (Basri 2014; 1994). According to PK3, PMOA and Islamic Missionaries only realize these bad symptoms when there is a case of apostasy or realize that some of the Muslim Orang Asli are starting to distance themselves from them or get information from others that there are individuals who have apostatized. This shows that Muslims seem to have failed to detect this problem from the beginning and this is one of the successes of their hidden strategies without having to move actively such as the $d a^{\prime}$ wah efforts carried out by PMOA and Islamic Missionaries themselves (Selangor Islamic Religious Council 2014).

According to PK3, the contextualization approach in the Christianization movement is said to be relaxed because they are present so quietly that it cannot be expected by PMOA and Islamic Missionaries. This unexpected presence caused them to be unaware that some Christian movers had already spread their message. In fact, PK3 acknowledges that Christian preachers are more knowledgeable about how to attract the hearts of Orang Asli than PMOA and Islamic Missionaries themselves. According to PK5, once upon a time the Christianization movement among the Orang Asli community was made up of Batak tribes, but now it is being pioneered by tourists who come, especially from Korea. They enter the village of the Orang Asli community as tourists for a period of time then they go out for a while to come back to renew the visa alone (Omar, 2012; 2013).

According to PK3, a similar situation has occurred in the Lubuk Cepa Orang Asli village. The village was originally inhabited by almost all of the Orang Asli Muslims. However, according to PK3, because at that time PMOA and Missionaries rarely went down to the village to meet the Orang Asli there, almost all the villagers were successfully Christianized by Christian preachers. According to PK3, at that time, two Indonesian women from Flores lived for seven months in the Orang Asli village. Their arrival was initially as tourists, but unawarely they spread Christian teachings. Things like this are worrying will continue to happen among the Orang Asli Muslim community because it indirectly disrupts the continuity of the efforts of the PMOA and Islamic Missionaries.

\section{Humanitarian Aid Approach}

The presence of Christian preachers in an Orang Asli community led to a mission to spread Christianity. The arrival that brings great goals is accompanied by a humane approach to cater to the needs of the local community. This can be done by providing assistance to the target group in the form of education, skills and daily needs, as well as social assistance. 
Matters involving the relationship of the Christianization movement and education in Malaysia attracted the interest of researchers such as Chong (2010); Diana and Ngu (2014) Most Orang Asli communities, especially the elderly, are illiterate and their level of thinking is low because they do not get formal education. According to PK4, many Orang Asli people who have embraced Islam whose age has reached the age of late, but still have not been able to recite one important verse of al-Quran like verse al-Fatihah fluently. Similarly, the activities and programs implemented such as religious talks, dialogues and workshops cannot be conducted formally and use language that is difficult to understand in terms of terms in a particular discipline even though most preachers are already able to speak in the Orang Asli language. Since their level of thinking is still low, this situation makes them think less, find it difficult to understand and appreciate what the preacher is conveying. Because the Orang Asli did not think enough, they were easily influenced by the persuasions, bribes and appeals that came from Christian preachers.

However, according to PK5, this low level of Orang Asli thinking and understanding will not be an obstacle and a challenge to Christian activists. Although Christian mobilizers cannot speak English well, but they tried to make Orang Asli likes and comfortable to communicate with them. Christian mobilizers are also involved in organizing programs that are similar to those implemented by the PMOA and Islamic Missionaries. They do a lot of planning to organize something by choosing the right day and time. Although the program sessions could not be delivered in the tribal language of the local Orang Asli community but they will ensure that the theme of the program is in line with the favorite habits of the Orang Asli. Program programs are usually interspersed with crowded events and food and drink that are indeed popular with the Orang Asli community.

Apart from that, according to Mohd Yunus (2010), Orang Asli education is often overlooked and given less coverage because the majority of the community considers these minorities do not want development. However, the results of the study found that among other efforts for Christian preachers to approach the Orang Asli community is through education. According to PK6, Christian preachers for example help weak children in Mathematics and English subjects by holding extra classes. Additional classes conducted are free and classes are conducted continuously (Mujani and Yusuf, 2010). They made the churches in the villages of the Orang Asli community a place of study. Indirectly this method brings more Indigenous people closer to the church. Such a technique as Kelly (2018) once stated that one of the ways to attract new members to the church within the framework of the growth of a church is to bring new faces into the church through someone known as friends, neighbors and church staff. In addition, according to Corley (2018), the interaction between Christianity and a society is evident through the strong relationship between the church and society when the church has a contribution to improve the quality of life such as in the form of education, law, economy, culture, politics and morals. Therefore, according to PK4, it is not surprising that the extra classes conducted by the church received a good response from the Orang Asli because it did not bother parents to send their children out to school to get extra classes which are not necessarily given for free.

According to PK4, Christians have their own school. Each of the Orang Asli children aged 3 years and above are sent to the school for their studies. Therefore, they do not have the opportunity to leave even though the Department of Community Development (KEMAS) has provided KEMAS Training Academy (AKK), KEMAS Training Institution (ILK), and KEMAS Training Center (PLK) to the Orang Asli community. Due to the presence of Christian preachers to the Orang Asli villages with the aim of providing the education, they received permission 
from the Department of Orang Asli Development (JAKOA) as well as permission and support from Batin, so no party was able to prevent their arrival. In fact, according to PK3 and PK4, apart from Christian preachers conducting extra classes, they also promise that if there are among the smart Orang Asli family members, they will be sent to further their studies at higher educational institutions in the field of Christian knowledge and have a need for complete life. After finishing his studies, Orang Asli children are sent back home to continue the Christianisation movement among local Orang Asli communities to ensure that the movement continues to persist. In fact, according PK3 Orang Asli children who get high Christian education will be appointed as pastors after returning home to the village.

Christian preachers also took advantage of the Orang Asli living environment, most of which were in poverty, by bribing various material aids and facilities (Harun et. al., 2006). Orang Asli in Gopeng and Kampar districts depend on living by earning a living from natural resources such as hunting, farming, fishing and finding forest products such as rattan and agarwood. According to PK3, there are now a number of Orang Asli who are starting to venture out of the village to make a living in towns nearby. For example, they work in restaurants, supermarkets as salesmen, laborers, cleaners and so on. This situation caused them not to be much in the village but to go outside into the forest for a long time. Because they were busy working outside, they no longer attended the guidance classes conducted by the preachers. Indirectly, according to PK3, da'wah efforts do not seem to be able to be conveyed perfectly to the whole village.

The results of the study also found that Christian preachers took the opportunity by helping the Orang Asli who were in a difficult situation, for example, by providing money, food and other needs according to the difficulties that are being experienced by the Orang Asli. In other words, Christian preachers are good at finding space and opportunities from the poverty and hardships of the Orang Asli to provide assistance to them. According to PK1, PMOA and Islamic missionaries can anticipate apostasy after the Orang Asli begin to distance themselves from them or refuse to accept certain assistance. For example, when there is a PMOA or Islamic Missionary who wants to help repair the door of a damaged Muslim Orang Asli house, but the help is rejected by stating that they can fix it themselves. According to PK1 from a cold attitude that is far different from the previous one allows PMOA and Christian Missionaries to know that they have started to deviate and be influenced by Christian teachings.

The study found that although the Ministry of Health is concerned about the health of the Orang Asli (Saharuddin 2018), Christian activists are also concerned about the condition of the Orang Asli by providing medical and medical examination assistance. Even in the study of Mujani and Yusuf (2010), it is common for Christian activists to offer and provide health services for free. In this regard, in the observation of PK4, if Christian activists find out that some members of the Orang Asli family are unhealthy, they go down to visit by providing medical help. The host provided food and the Christian preachers held a prayer ceremony supposedly praying for the well-being of the Orang Asli. Activities of visiting are continued from one house to another. For Christians, such activities are like the practice of giving alms in their religion. According to PK5, the disaster or hardship that befell the Orang Asli community was made a valuable opportunity for the Christian movement to Christianize. They offer help, but must be rewarded with apostasy that is to leave the religion of Islam. The results of the study found that Christianization through the help of examination and medicine has occurred repeatedly. They use adversity as a ticket to help members of society who end up bringing them closer to Christianity. Such an approach was once reported by Christian 
(2016) in reliefweb that the organization launched a new framework to build resilience in a poor and marginalized society. The framework contains several principles for creating a sustainable society with long-term impact. Among them is the need to enhance the integration between humanitarian aid and development in certain areas such as community health.

\section{Psychological Approach Through the Message of Love and Affection}

Among the topics in Christian teaching is about the importance of one's love and affection for god and neighbor (Wood, 2016). They also emphasize the psychological aspect of love and affection is not only focused on husband and wife and family but also on a certain population and society (Titus and Scrofant, 2012). Thus, in the aftermath of the tsunami in Aceh in 2005, a similar situation was reported in The Guardian in the writings of Burke (2005) that the Christian activists do not wear cross and do not promote a particular denomination as the church for help tsunami victims. They were reported as saying by the message 'Light of Love for Aceh' they can help the victims and hopes to bring 50 children to the house of a Christian orphanage in Jakarta. They reportedly wanted to expose the child to Christian values in the context of "the love of Christ".

In the context of this study, the Christianization movement is also done by spreading the message of love and affection when interacting with the Orang Asli community. According to PK6 that he prefers Christianity to Islam because of the religious guidance given by Christian movers based on love and affection. For the Orang Asli, Christian teaching was considered not to burden them with slander and condemnation because Jesus forbade such things at all. For PK6, those who apostatize believe that if they convert to Christianity, they will both enter heaven whether they are rich, evil or good. However, he knew in the teachings of Islam that if they want to enter paradise they need to repent to get Allah's forgiveness. For him to get the forgiveness of Allah according to the teachings of Islam troubles the Orang Asli like him. This added by the notion of indigenous peoples that still exist until now against the Malays by the events of the past and is happening because they assume a model Muslim Malays. According to PK1, the neighboring community did not set a good example by drinking alcohol, dancing in ceremonies even more so than the Orang Asli themselves, often looked down on and had no respect or love for them at all. Thus, they consider the behavior of the Malay Muslims in such a contrast to Christian teachings brought by the Christian preachers who placed more importance on compassion when interacting and associate with them.

However, according to PK4, the issue between Orang Asli and the Malays actually not a religious issue. However, the actuality due to the proximity of friendship between the Malays and Orang Asli itself has been way distant since the past. This is because the Orang Asli looked down and disgusted by the Malays. The study found that as the Orang Asli associates Malays with Islam within the meaning of the word Islam is Malay and Malay is a Muslim, then all these events made the two related affairs that cannot be separated. Therefore, they think that if they embrace Islam it will bring them problems compared to Christianity which always cares about love and respect for them.

\section{Caderization Leadership Approach}

The study found that Christian preachers appointed Orang Asli as priests in an Orang Asli village to implement caderization leadership programs. Such an approach is also known as "leadership development in the local church" as discussed by Moss (2014). Based on the testimony of PK6, the head of the church in Kampung Ulu Groh named Bah Denal is the Orang 
Asli of the village. According to him, the Orang Asli are easier to communicate and understand what Christian preachers are trying to convey when their leaders are from among themselves. As a result of higher studies of Christian religious knowledge than other Orang Asli, the study found that Christian activists can appoint their own Orang Asli as priests for a village. This can make it easier for them to attract more Orang Asli to embrace Christianity. In addition, according to PK3, Christian preachers appointed one of the Orang Asli family members such as a son in a family to represent them in delivering their movement. This Christian effort is to make it easier for the whole family to believe in Christianity when the message is delivered by their own family members. Children who are sent to study outside Peninsular Malaysia such as in Sabah and Sarawak for higher Christian knowledge will return to their hometowns and help spread Christianity. In addition, everyone who helped the Christianization movement was given a decent wage. According to PK4, the wages earned by these Christian activists are worth more than the remuneration earned by PMOA and the Islamic Missionaries themselves.

\section{Conclusion}

The seriousness of Christian activists in carrying out Christianization efforts in the Muslim community is a manifestation of their reluctance to recognize and acknowledge the greatness of Islam until the hereafter as stated in the Qur'an. Therefore, they plan carefully to realize their aspirations as contained in the $3 \mathrm{G}$ mission, namely Gold, Gospel and Glory. They devise strategies, methods and forms to spread Christian teachings, in particular, to attract as many people as possible to Christianity. By studying sociology, anthropology and psychology certain groups such as the Orang Asli make it easier for them to achieve the set goals. In addition, by examining all the actions carried out by the Muslim preachers to the minority group, they make various perceptions to create suspicion and weakness on the part of the Muslim preachers. They also take advantage of the shortcomings of the Orang Asli by offering various material assistance and gifts so that they can follow the teachings of Christianity.

Based on the order of priority, this study found that the form of leisure and entertainment is the most prominent form of Christianization movement implemented by Christian activists. This kind of approach has given highly impact on missionary activities and influenced Orang Asli much. Therefore, stakeholders with the da'wah of the Orang Asli community such as preachers from government agencies and non-governmental organizations need to formulate an effective $d a^{\prime}$ wah strategy in an integrated manner so that the message of Islam can be conveyed to them. Preachers need to equip themselves with certain preparations such as Islamic-based knowledge (such as faith, jurisprudence and morality) and humanity (such as sociology, anthropology, psychology and communication) to approach these groups. In addition, preachers need to have the skills to read the atmosphere and environment of the Orang Asli community through the approach of fiqh al-waqi (an understanding of contemporary problems or problems based on reality) and fiqh alawlawiyyat (an understanding of priorities) so that da'wah to the group continues to be relevant. What is more important is the determination of the preachers to protect the faith of Muslims among the Orang Asli so that they are not influenced should be more concerned with the efforts of the Christianization movement so that the faith of the Muslim Orang Asli community is maintained and their solidarity with Islamic teachings. Preachers should not underestimate and take lightly the external challenges that come from the religious teachings 
of a missionary nature to challenge the faith and implementation of Islamic teachings among the Orang Asli.

\section{Contribution of the Study}

The present study concerning Christian movement among Orang Asli Muslim in State of Perak, Malaysia contributes to the theoretical and contextual aspects related to the field. Theoretically, it provides knowledge related to Christian mission which accomplished through 3Gs, namely: God, glory and gold. This concept of $3 \mathrm{Gs}$ not merely remain as a principles of missionary approach but rather applicable in missionary works at the ground. The study also has a significant to the existing knowledge related to Christian mission and movement. In addition, several approaches like contextualization, humanitarian aids and psychological approach applied by Christian Movements in Perak in particular and in other part of the world can be applied by Muslim preachers in their da'wah movements (Islamic missionary works). Not only that, these approaches provide some ideas to Muslim preachers how they can develop some sort of strategic planning and management in the field of $d a^{\prime} w a h$ to engage with their target groups among Orang Asli community. They should bring shining on the plight of Muslim Orang Asli in order to upgrade their quality of islamization in term of belief, Islamic practices and moral values. In addition, the findings could provide valuable inputs to stake holders related to Muslim Orang Asli community how to strengthen $d a^{\prime}$ wah approach and develop new methodology of $d a^{\prime} w a h$ to Orang Asli especially in order to face as well as overcome some deislamization challenges such as Christianization movement.

\section{References}

Abdul Rahman, I. (2000). Gerakan gereja Katolik di Malaysia. Bangi: Penerbit Universiti Kebangsaan Malaysia.

Abdullah, R. (2015). Cabaran dakwah dalam masyarakat Orang Asli. National Conference on Pembangunan Insan Pimpinan Masyarakat Orang Asli, Port Dickson Negeri Sembilan, Malaysia, 1-15.

Abdullah, R. (2014). Orang Asli: Pembangunan dan transformasi. Kuala Terengganu: Penerbit Universiti Sultan Zainal Abidin.

Aini, Z., Don, A. G., Mokhtar, A. I., \& Fauzi, A. N. U. (2019). Strategi komunikasi pemujukan dalam penyampaian mesej Islam kepada masyarakat Orang Asli di Selangor. Al-Irsyad: Journal of Islamic and Contemporary Issues, 4(1), 12-26.

Aini, Z., \& Don, A. G. (2020). Amalan kemahiran komunikasi pendakwah dengan masyarakat Orang Asli di Malaysia. BITARA International Journal of Civilizational Studies and Human Sciences, 3(4), 83-100.

Anon. (n.d). Kehidupan, budaya \& pantang larang Orang Asli. Kuala Lumpur: Jabatan Hal Ehwal Orang Asli, Kementerian Pembangunan Luar Bandar.

Anon. (2019a). K-pop and Christianity. Access via http:///xrhythms.co.uk.

Anon. (2019b.) 10 great Christian songs Sung by K-pop idols. Acces via http:///whatthekpop.com

Anon. (2014). Data maklumat asas. Kuala Lumpur: Bahagian Perancangan dan \Penyelidikan JAKOA.

Anon. (2014). Pendedahan agenda Kristian. Shah Alam: Majlis Agama Islam Selangor

Basri, G. (2014). Gerakan Kristian. Bangi: Penerbit Universiti Kebangsaan Malaysia.

Basri, G. (1994). Kristianisasi sebagai sebuah gerakan: Satu tinjauan sosiologi.

Kajang: Institut Pengajian Ilmu-ilmu Islam. 
Bridges, E. (1997). Of 'Jesus Mosques' and Muslim Christians. Mission frontiers Pasadena, CA: USCWM, July/October 1997.

Burke, J. (2005). Religious aids group try to convert victims. The Guardian. Accessed via www.theguardian.com.

Carey, I. (1976). The aboriginal tribes of Peninsular Malaysia. Kuala Lumpur: Oxford University Press.

Choi, J. (2019). What Western Christians can learn from the BTS phenomenon. Access via https://www.thegospelcoalition.org/article/bts-phenomenon/

Chong, E. C. (2010). Modernity, state-led Islamisation and the Non-Muslim response: A case study of Christians in Peninsular Malaysia. PhD Thesis, Universiti Sains Malaysia.

Christian, A. (2016). Resilience framework: Christian aid's Approach. Accessed via www.reliefweb.com

Dana, R. (2004). Ritual music and Christianization in the Toraja's Highlands, Sulawesi. Ethnomusicology, Society for Ethnomusicology. 48(3), 378-404.

Diana, W., \& Ngu, I.T. (2014). A 'double alienation' the vernacular Chinese Church in Malaysia. Asian Journal of Social Science. (42), 262-290.

Don, A. G. (2014). Masyarakat Orang Asli Muslim Malaysia: Senario dan realiti kefahaman dan penghayatan Islam. International Conference on Dakwah and Ethnicity, Sabah, Malaysia, 1-11.

Edo, J. (2010). Adat dan nilai masyarakat Orang Asli. Kuala Lumpur: Universiti Malaya.

Endicott, K. (2016). Introduction to Orang Asli. In Malaysia's Original People: Past, Present and Future of the Orang Asli (Ed.). Singapore: NUS Press, 1-38.

Hidajat, D. (2018). Gereja di rumah: Kontekstualisasi fungsi-fungsi rumah dalam masa Perjanjian Baru untuk pekabaran Injil. Veritas: Journal Teologi dan Pelayanan. 17(2), 107-117.

Hoefer, H. (2001). Churchless Christianity. Pasadena, CA: William Carey Library.

Hoefer, H. (2015). Community vs. belief: Respecting cultural belonging in Evangelism. International Journal of Frontier Missiology 32(3), 147-151.

Jalaudin, N. H., \& Ahmad, Z. (2011). Hallyu di Malaysia: Kajian sosiobudaya. Malaysian Journal of Communication. 27(2), 203-219.

Kelly, L. (2018). 5 ways to attract new members to your church.Accessed via www.boxcast.com

Komar, J. dan Amir Zal, W. A. (2014). Adat Orang Asli Suku Temuan. Kuala Lumpur: Dewan Bahasa dan Pustaka.

Leary, J. D. (1995). Violence and the dream people, The Orang Asli in the Malaysian Emergency 1948-1956. USA: Ohio University Press.

Lee, Y. L., Jung, M., Nathan, R. J., \& Chung, J-E. (2020). Cross-National study on the perception of the Korean wave and cultural hybridity in Indonesia and Malaysia using discourse on social media. Sustainability. 12, 1-33.

Martin, C. G. (2012). A Biblical critique to C5 strategies among Muslims. Accessed via http://ojs.globalmissiology.org/index.php/english/article/view/1042/2432

Mashoko, F. (2005). The need for contextualization in inter-cultural communication of the Gospel. Master Thesis of Theology, University of South Africa.

Nor, M. H. (1994). Christianity and the peripheral community: A Malaysian case. The Journal of Sophia Asian Studies. 12, 143-158. 
Mohamed, N. A., \& Isa, M. M. (2009). Gerakan Orientalisme dan Kristianisasi. Kuala Lumpur: Hijjaz Record Publishing.

Harun, M. F., Idris, N., Berma, M., \& Shahadan, F. (2006). Kemiskinan di kalangan masyarakat Orang Asli. Jurnal Ekonomi Malaysia. 40, 95-101.

Zain, M. J., \& Alwi, E. A. Z. (2017). Aktiviti dakwah JAKIM terhadap masyarakat Orang Asli: Pelaksanaan dan cabarannya. Malaysian Journal for Islamic Studies 1, 45-61.

Yunus, M. A. R. (2010). Pendekatan dakwah melalui pendidikan kepada Masyarakat Orang Asli di Negeri Pahang. Shah Alam: Penerbit Karisma Publications.

Mokhtar, H., \& Aini, Z. (2014). Dakwah Islamiah Kepada Orang Asli di Pulau Carey Banting Selangor: Isu, cabaran, dan permasalahan. International Conference on Dakwah and Ethnicity, Sabah, Malaysia, 40-56.

Moss, B. K. (2014). Leadership development in the local Church: An intentional strategy for developing leaders at every level. PhD Thesis. Liberty University Baptist Theological Seminary, Lynchburg Virginia.

Mujani, W. K., \& Yusuf, N. (2010). Islam dan missionari di Sarawak: Kesan terhadap pendidikan pada zaman Crown Colony, 1841-1941. Sosiohumanika. 3(2), 219-242.

Musa, M. (1996). Orang Asli di Tanah Melayu: Satu evolusi hubungan dengan pemerintah dan masyarakat luar dari akhir abad ke-19 hingga 1960-an. Jurnal Ilmu Kemanusiaan, Vol.3, 12-27.

Omar, A. K. (2012). Dakwah Islamiyyah dalam mendepani gerakan pemurtadan di Malaysia. National Conference on Dakwah, Kuala Lumpur, 1-25.

Omar, A. K. (2013). Kristianisasi dan dakyah halus yang menyerap ummat: Suatu fakta. Konvensyen ilmuan Islam sempena ulang tahun hari keputeraan ke- 85 Duli Yang Maha Mulia Paduka Seri Sultan Perak Darul Ridzuan, Perak Darul Redzuan, Malaysia, 1-25.

Raffe'i, B. A. (1968). Religion in Social Change among the Orang Asli. Kuala Lumpur: Jabatan Hal Ehwal Orang Asli (JHEOA).

Redzuan, M., \& Abdul Rahman, A. R. (2008). Integrasi Orang Asli dalam masyarakat arus perdana. In Orang Asli: Isu, transformasi dan cabaran, Ma'Rof Redzuan dan Sarjit S. Gill (Ed.), (pp. 40-65). Serdang: Penerbit Universiti Putra Malaysia.

Sahad, M. N., \& Sa'ari, C. Z. (2005). Islamisasi \& Kristianisasi di kalangan Orang Asli Temuan, Broga. Jurnal Afkar (6), 37-54.

Saharuddin, S. N. (2018). Pembangunan prasarana di perkampungan Orang Asli. Technical report for research project, Bachelor of Science, Fakulti Alam Bina, Universiti Teknologi Malaysia.

Hussin, S. A. R. (2009). Dakwah kepada Orang Asli di Malaysia: Permasalahan dan halangan. Jurnal Usuluddin. 25(1), 155-184.

Tanudjaja, R. (2000). Kontekstualisasi sebagai sebuah strategi dalam menjalankan misi : Sebuah ulasan literatur. Veritas: Jurnal Teologi dan Pelayanan. 1(1), 1927.

Tennent, T. C. (2019). Biblical and historical reflection on ecclesiology and insider movements. Accessed via http://btdnetwork.org/wp-content/uploads/2014/08/Biblical-andHistorical-Reflection-on-Ecclesiology- and-Insider-Movements-Tim-Tennent.pdf.

Tennent, T. C. (2006). Followers of Jesus (Isa) in Islamic mosques: A close examination of C-5 'High-Spectrum' contextualization. International Journal of Frontier Missions. 23(3), 101-115.

Tennent, T. C. (2005). The challenge of churchless Christianity: An evangelical assessment. International Bulletin of Missionary Research. 29(4), 171-177. 
Titus, C. S., and Scrofant, P. (2012). The art of love: A Roman Catholic psychology of love. Journal of Psychology and Christianity. 31(2), 118-129.

Travis, J. (1998). The C-1 to C-6 spectrum. Evangelical Missions Quarterly. 34(4), 407408.

Williams, M. S. (2011). Revisiting the C1-C6 spectrum in Muslim contextualization. Missiology: An International Review. XXXIX(3), 335-351.

Wood, H. (2016). A Christian understanding of the significance of love of oneself in loving God and neighbour: Towards an integrated self-love reading. HTS Theologies Studies/Theologies Studies. 72(3), 1-10.

Yahya, S. F., \& Annuar, S. N. (2018). Hallyu: Kimchi, budaya popular dan kuasa lunak Korea Selatan. Petaling Jaya: Strategic Information and Research Development Centre. 